\title{
PCR-RFLP method to distinguish Frankliniella occidentalis, Frankliniella intonsa, Frankliniella pallida and Frankliniella tenuicornis
}

\author{
Arnika Przybylska ${ }^{1 *}$, Żaneta Fiedler ${ }^{2}$, Aleksandra Obrępalska-Stęplowska ${ }^{1}$

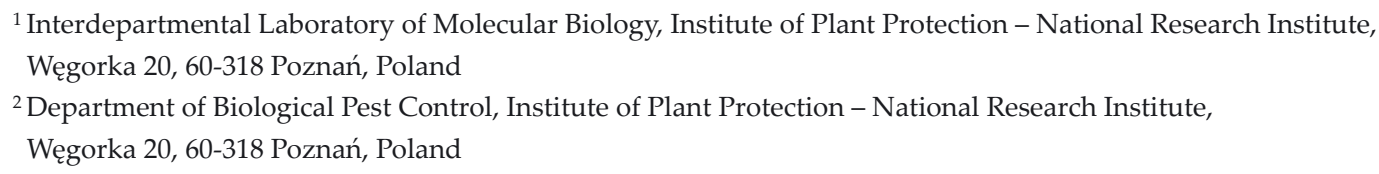

Received: November 30, 2015

Accepted: February 14, 2016

\begin{abstract}
Thrips from the genus Frankliniella (Thysanoptera, Thripidae) are phytophagous on crops and wild plants. Some of them cause slight economic damage, however, others including F. occidentalis and F. intonsa are responsible for considerable losses in crop production. Moreover, they constitute a double threat for host plants by not only feeding on them but also vectoring viruses, some of which are on the quarantined list of the European Plant Protection Organization. The rapid detection and differentiation between more and less harmful Frankliniella species is, therefore, important in order to combat the pests at the time of their appearance. In this study, we have undertaken to develop a method of detecting F. occidentalis, F. intonsa, F. pallida, and F. tenuicornis. The protocol is based on PCR amplification of ITS1 rDNA fragments of these insects using universal primers pair giving products of slightly distinct length for studied insects. Restriction enzymes digestion which is easy to interpret, allows for visible differentiation of all these Frankliniella species. The method was shown to be species-specific and sensitive. Even single specimens in either the larvae or adult stage could be distinguished.
\end{abstract}

Key words: Thrips, molecular diagnostics, pest control, detection, Frankliniella occidentalis, Frankliniella pallida, Frankliniella tenuicornis, Frankliniella intonsa

\section{Introduction}

Thrips are one of the most important pests occurring on vegetables and ornamental plants in greenhouses, and on vegetables in fields in Poland. About 6,000 species of thrips are known throughout the world, with about 600 in Europe, of which about 220 occur in Poland (Kucharczyk 2007). About 230 species are listed in the genus Frankliniella, with up to 130 further names placed into synonymy (Nakahara 1997). This high rate of synonymy is due to unrecognized variability in size and color of many species. In Poland, species included in the Frankliniella genus (Thysanoptera, Thripidae) are represented mainly by Frankliniella occidentalis (Pergande), Frankliniella intonsa (Trybom), Frankliniella pallida (Uzel), Frankliniella tenuicornis (Uzel), and rarely by Frankliniella nigriventris (Uzel) and Frankliniella tristis (Priesner) (Sierka and Gocyła 2004). All of these are phytophagous on crops and wild plants and are responsible for direct damages (feeding and oviposition wounds). Moreover, F. occidentalis and F. intonsa are important vectors of tospoviruses such as tomato spot wilt virus (TSWV), tomato chlorotic spot virus (TCSV), groundnut ringspot virus (GRSV) or impatiens necrotic spot virus (INSV) (Wang et al. 2010).
Frankliniella occidentalis (western flower thrips) is on the EPPO A2 List of pests recommended for regulation as quarantine pests (EPPO). This pest is highly polyphagous with a wide host range. It spreads from horticultural and ornamental crops (such as pepper, beans, carnations, roses and gerbera) to strawberry plants and trees (table grapes and peach). With regard to their impact on agricultural systems, western flower thrips can be considered as the most invasive pest introduced into Europe and responsible for the greatest damage in crops. For example it can cause up to $70 \%$ yield losses of greenhouse cucumber (Marullo 2002). Frankliniella intonsa (flower thrips), which in some seasons can cause significant damage, is found in Poland (Pobożniak 2011). It also has a wide host plant range, spreading from field crops to greenhouse and wild plants and can colonize Rosaceae (apple, pear, cherry, plum) and herbaceous plants (grasses). Frankliniella pallida can not be considered as a pest, since it lives mainly on wild plants such as Trifolium, Ranunculus, Cichorium, Leucanthemum, Brassica nigra (Marullo 2003). Frankliniella tenuicornis is host-specific on wild and cultivated Gramineae. Its injuries produce grain malformations or complete sterilization. Morphological identification of thrips 
species is not easy and possible only for professional taxonomists.

Proper identification of species is essential to successfully control the number of pests. The earlier a pest is identified the better the chance to take appropriate steps to limit its spreading. It is also important to distinguish between non-pest thrips species, pests causing moderate losses and species causing huge damages in crops in order to take immediate measures to fight the latter. Due to the similarity between Frankliniella species, especially in the larval stadium and similar host range, morphological identification is difficult, especially for non-taxonomists.

For this reason molecular biology can be very useful for rapid, sensitive and reliable identification. Molecular diagnostic protocols for identification of economically important pest species exist for many insects, including thrips (Kraus 1998; Moritz 2000; Obrepalska-Steplowska et al. 2008; Huang et al. 2009; Pumariño et al. 2011; Varadínová et al. 2015). Also several protocols were developed for quarantine thrips species (e.g. Przybylska et al. 2015). In this study PCR-RFLP (Polymerase Chain Reaction - Restriction Fragment Length Polymorphism) was used which allows for the amplification of a conserved region of DNA sequence using PCR followed by the digestion of the amplified fragment with appropriate restriction enzymes which enables the detection of genetic variation between identified species. There are two other protocols for distinguishing thrips species using PCR-RFLP assay (Brunner et al. 2002; Mainali et al. 2008) but not for all four species analyzed in this study. Other protocols for thrips detection are based on real-time PCR (Huang et al. 2010), PCR (Zhang et al. 2012) or Loop-mediated Isothermal Amplification (LAMP) (Przybylska et al. 2015).

Most molecular diagnostic protocols are based on mtDNA or rDNA regions. There are some protocols for thrips species based on $m t$ COI (Brunner et al. 2002; Zhang et al. 2012) but there are some reports about several intraspecific variants of this region in the case of thrips (Rebijith et al. 2012) which might result in an ambiguity of detection with this marker. We chose the ITS1 rDNA region because sequences analysis done in our previous study (Przybylska et al. 2015) demonstrated its interspecific variations between Frankliniella and Thrips species and the stability within the studied species. Therefore we found appropriate fragments which made it possible to design universal primers and the amplification of DNA from all four analyzed species. Moreover, the ITS1 region differs in length for each studied species. The method described in this study makes it possible to detect four Frankliniella species and differentiate between them without DNA isolation.

\section{Materials and Methods}

\section{Insect samples}

Material for the study consisted of populations of different thrips species considered as positive controls (F. occidentalis, F. intonsa, F. pallida, F. tenuicornis) and negative controls.
There remaining species are listed in table 1. For molecular analysis both larvae and adult specimens were taken.

\section{Genomic DNA extraction from thrips samples}

Thrips samples were collected and suspended in $70 \%$ ethylene alcohol. DNA extraction was performed from 1-3 thrips specimens using DNeasy Blood \& Tissue Kit (Qiagen) and obtained in the final volume of $100 \mu \mathrm{l}$ and concentration $5-10 \mathrm{ng} \cdot \mu^{-1}$.

\section{Design of four Frankliniella species specific primers}

Sequences of 18S-ITS1-5,8S-ITS2-28S rDNA region from a number of thrips species (F. occidentalis, F. intonsa, F. pallida, F. tenuicornis, Thrips palmi, T. tabaci, T. major, T. trehernei, T. sambuci, T. simplex, T. roepkei), obtained during our previous study (Przybylska et al. 2015) and F. schultzei sequence downloaded from NCBI databases (National Center for Biotechnology Information) were aligned using BioEdit software (Hall 1999) and regions conserved only for Frankliniella species were chosen for designing forward and reverse primers amplifying products of different lengths. Next, this Frankliniella species sequences alignment was used to indicate restriction enzymes sites which would allow for differentiation between F. occidentalis, F. intonsa, F. pallida and F. tenuicornis.

\section{PCR assay specific for Frankliniella species}

Degenerate primers pair designed for this study (FrUNIF: GATRCGACTGTCAGAGWAC and FrUNIR: GATACCGACACTTCATCTG), giving products of distinct lengths for each tested species, were tested in PCR reaction with DNA isolated from populations of F. occidentalis, F. intonsa, F. pallida, and F. tenuicornis. To test method reproducibility, ten F. occidentalis populations and seven F. intonsa populations were tested. Moreover, the combination of DNA isolated from F. occidentalis and F. intonsa mixed in equimolar ratio in one reaction tube was included. To exclude cross-reactions, DNA isolated from many other Thrips species (Table 1) was also tested as well as no template control to test for the reagents contamination. All PCR reactions were performed in the mixture containing $1 \mu \mathrm{l}$ DNA template, $1 \mu \mathrm{M}$ of each primer, $5 \mu \mathrm{l}$ of DreamTaq Master Mix (Thermo Scientific) and sterile, distilled water up to $10 \mu \mathrm{l}$. The amplification conditions were as follows: denaturation for $3 \mathrm{~min}$ at $95^{\circ} \mathrm{C}$ followed by 35 cycles of $30 \mathrm{~s}$ at $95^{\circ} \mathrm{C}, 30 \mathrm{~s}$ at $57^{\circ} \mathrm{C}, 30 \mathrm{~s}$ at $72^{\circ} \mathrm{C}$; the final extension for $5 \mathrm{~min}$ at $72^{\circ} \mathrm{C}$ (Mastercycler Personal, Fermentas). After reaction, $3 \mu \mathrm{l}$ of the final mixture were run on $1 \%$ agarose gel and visualized with Midori Green stain (Nippon) in the gel documentation system (Infinity, Vilber) and the remaining volume of the PCR product was taken for restriction enzyme digestion in RFLP analyses.

\section{Restriction Fragment Length Polymorphism (RFLP) assay}

RFLP assay was performed using $7 \mu \mathrm{l}$ of PCR product as a template. To each reaction $1 \mu \mathrm{l}$ of FastDigest Buffer (Thermo Scientific), and $5 \mathrm{U}$ of FastDigest enzymes Tru1I 
Table 1. Thrips and Frankliniella populations used in this study

\begin{tabular}{|c|c|c|c|}
\hline Species & Origin & Host plant & GenBank accession number \\
\hline Frankliniella occidentalis 1 & Poland & Cucumis sativus & KM886242 \\
\hline Frankliniella occidentalis 2 & Poland & Dendranthema indica & - \\
\hline Frankliniella occidentalis 3 & Poland & Cucumis sativus & - \\
\hline Frankliniella occidentalis 4 & Poland & Cucumis sativus & - \\
\hline Frankliniella occidentalis 5 & Poland & Cucumis sativus & - \\
\hline Frankliniella occidentalis 6 & Poland & Solanum lycopersicum & - \\
\hline Frankliniella occidentalis 7 & Poland & Cucumis sativus & - \\
\hline Frankliniella occidentalis 8 & Poland & Eupatorium sp. & - \\
\hline Frankliniella occidentalis 9 & Poland & Cucumis sativus & - \\
\hline Frankliniella occidentalis 10 & Poland & Solanum melongena & - \\
\hline Frankliniella intonsa 1 & Poland & Nemesia strumosa & KM886243 \\
\hline Frankliniella intonsa 2 & Poland & Pelargonium hirsutum & - \\
\hline Frankliniella intonsa 3 & Poland & Lysimachia vulgaris & - \\
\hline Frankliniella intonsa 4 & Poland & Rosa sp. & - \\
\hline Frankliniella intonsa 5 & Poland & Trifolium sp. & - \\
\hline Frankliniella intonsa 6 & Poland & Gentiana pneumonanthe & - \\
\hline Frankliniella intonsa 7 & Poland & Gentiana asclepiadea & - \\
\hline Frankliniella pallida & Poland & Sedum acre & KM886244 \\
\hline Frankliniella tenuicornis & Poland & Zea mays & KM886245 \\
\hline Thrips major & Poland & Sambucus nigra & KM877309 \\
\hline Thrips menyanthidis & Poland & Menyanthes trifoliata & - \\
\hline Thrips nigropilosus & Poland & Ocimum basilicum & - \\
\hline Thrips palmi & Japan & Cucumis sativus & KM877305 \\
\hline Thrips origani & Poland & Origanum vulgare & - \\
\hline Thrips physapus & Poland & Ceantaurea jacea & - \\
\hline Thrips roepkei & Poland & Solanum dulcamara & KM877310 \\
\hline Thrips simplex & Poland & Gladiolus sp. & KM877312 \\
\hline Thrips sambuci & Poland & Sambucus nigra & KM877311 \\
\hline Thrips tabaci & Poland & Inula salicifolia & KM877307 \\
\hline Thrips trehernei & Poland & Tragopogon pratensis & KM877313 \\
\hline
\end{tabular}

and HinfI and sterile distilled water up to $10 \mu \mathrm{l}$ were added. Reaction was carried out for $30 \mathrm{~min}$ in $37^{\circ} \mathrm{C}$, and then the PCR-RFLP products were separated in $2.5 \%$ agarose gel and visualized with Midori Green stain (Nippon) UV lamp integrated in the gel documentation system (Infinity, Vilber)

\section{PCR-RFLP detection without DNA isolation}

PCR-RFLP assay was tested for F. occidentalis and F. intonsa specimens using one larva and without DNA extraction. To assess repeatability, five larvae from each species were taken and each one was crushed in a separate tube in $20 \mu \mathrm{l}$ of sterile distilled $\mathrm{H}_{2} \mathrm{O}$. The obtained suspensions $(2 \mu \mathrm{l})$ were taken as templates for PCR-RFLP analysis. Reactions were done under the previously described conditions.

\section{Results}

\section{Design of Frankliniella species specific primers and restriction enzymes sites}

In the first part of the study PCR primers were designed which enabled the detection of four analyzed Frankliniella species. Obtained sequences of primers were analyzed by last searches to exclude potential cross-reactions with non-target species. The BLAST analysis showed that the designed primers hybridize only to Frankliniella sequences. In the obtained alignment consisting of Frankliniella species, the species-conservative regions were indicated as targets for primers hybridization sites. Simultaneously, fragments localized between regions of primers hybridization and showing interspecies variability were found to serve as targets for species-specific restriction enzymes digestion, so they were suitable for four Frankliniella species differentiation (Fig. 1).

\section{PCR assay specific for Frankliniella species}

Under the described conditions, the PCR reaction gave single products with the following lengths: $326 \mathrm{bp}$ for F. occidentalis, $237 \mathrm{bp}$ for F. intonsa, $280 \mathrm{bp}$ for F. tenuicornis and $250 \mathrm{bp}$ for F. pallida. No cross-reactions were observed with thrips species taken as negative control: T. major, $T$. menyanthidis, T. nigropilosus, T. origani, T. palmi, T. physapus, T. roepkei, T. sambuci, T. simplex, T. tabaci and T. trehernei as well as no product was obtained for reaction mixture without insects' DNA template (Fig. 2). The reaction was repetitive for ten analyzed $F$. occidentalis populations and seven F. intonsa populations. Moreover, the combination of F. occidentalis and F. intonsa in one tube gave two bands with sizes specific for those species (Fig. 3A). 


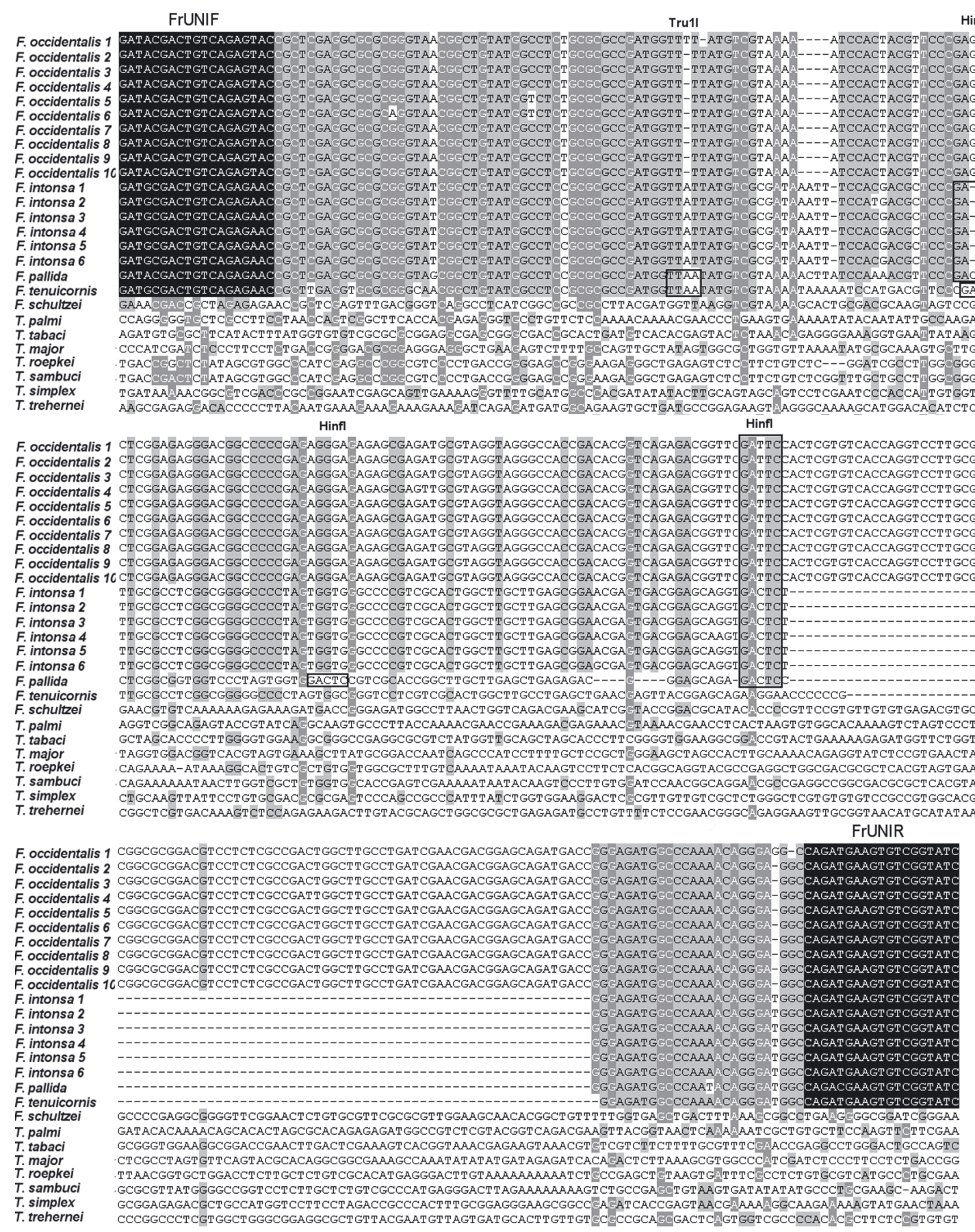

Fig. 1. Multiple sequence alignment of the rDNA region of analyzed thrips species with FrUNIF/R primers sequences (black) and restriction enzymes digestion sites (in frames). Visualization in GenDoc software (Nicholas et al. 1997)

\section{PCR-RFLP assay}

The PCR protocol allows for detection of four aforementioned Frankliniella species. To differentiate between them two restriction enzymes were selected (TruI, Hinfl) and applied in the extended version of PCR-RFLP. The patterns of the RFLP analysis were characteristic for each species (Fig. 3B) and their lengths were as follows: $190 \mathrm{bp}$ and $147 \mathrm{bp}$ for F. occidentalis; $102 \mathrm{bp}, 95 \mathrm{bp}$ and $50 \mathrm{bp}$ for F. intonsa; $68 \mathrm{bp}, 50 \mathrm{bp}, 44 \mathrm{bp}, 42 \mathrm{bp}$ and $35 \mathrm{bp}$ for F. pallida and $151 \mathrm{bp}, 68 \mathrm{bp}$ and $36 \mathrm{bp}$ for F. tenuicornis according to bioinformatics tools (NEBcutter V2.0) used for prediction of products fragments sizes after restriction enzymes digestion of Frankliniella DNA sequences used in this study. After gel electrophoresis some bands of similar sizes mi- grated together and some smaller ones were less visible on agarose gel but RFLP patterns differed significantly between analyzed species.

\section{PCR-RFLP sensitivity and detection without DNA isolation}

The sensitivity of the PCR-RFLP method was determined for larva of F. occidentalis and F. intonsa. Single larva samples (without DNA isolation) were subjected to PCRRFLP under the conditions described above. The method proved to be sufficiently sensitive to detect even one larva crushed in water without DNA extraction. Results were positive for all five replicates of F. occidentalis larvae as well as for F. intonsa larvae (Fig. 4). This also confirms the repeatability of the method. 


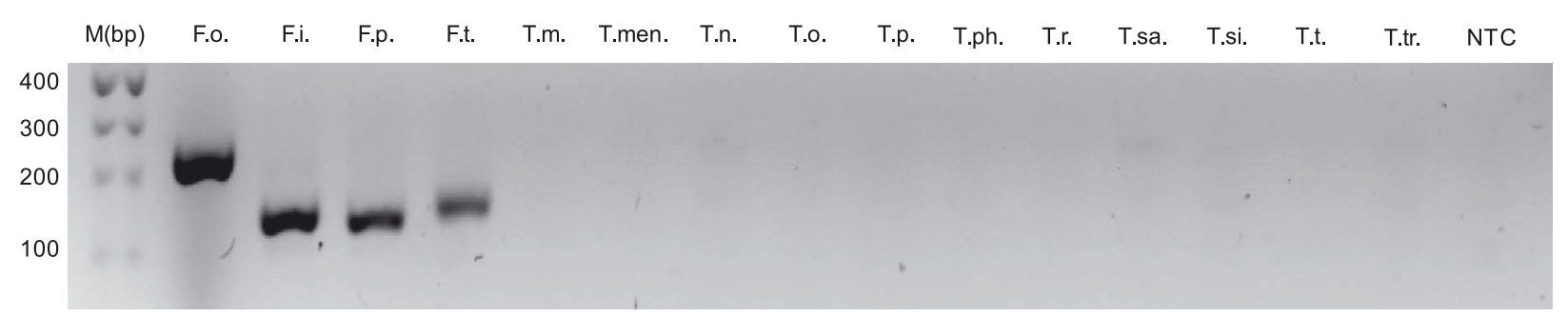

Fig. 2. The electrophoretic separation of PCR products obtained with FrUNIF/FrUNIR primers in agarose gel. Obtained products sizes were as follows: F. occidentalis -326 bp, F. intonsa -237 bp, F. tenuicornis -280 bp, F. pallida - 250 bp; F.o. - F. occidentalis, F.i. - F. intonsa, F.p. - F. pallida, F.t. - F. tenuicornis, T.m. - Thrips major, T.men. - T. menyanthidis, T.n. - T. nigropilosus, T.o. - T. origani, T.p. - T. palmi, T.ph. - T. physapus, T.r. - T. roepkei, T.sa. - T. sambuci, T.si. - T. simplex, T.t. - T. tabaci, T.tr. - T. trehernei, NTC - no template control, $\mathrm{M}$ - marker of molecular weight (Nova 100 bp, Novazym)

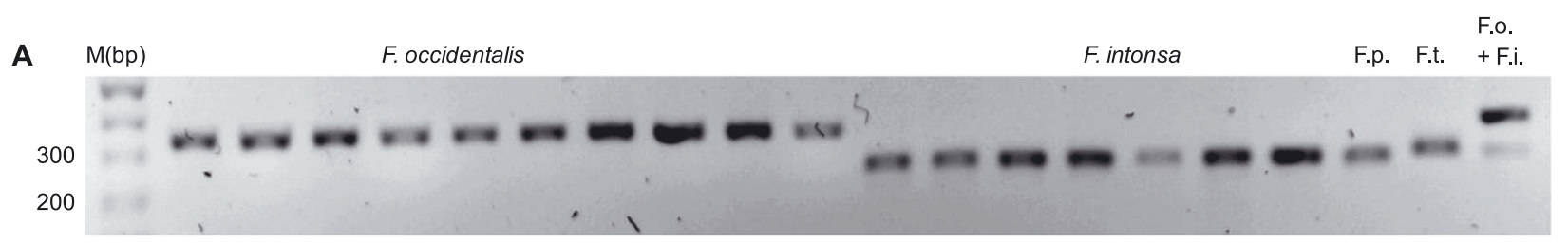

B

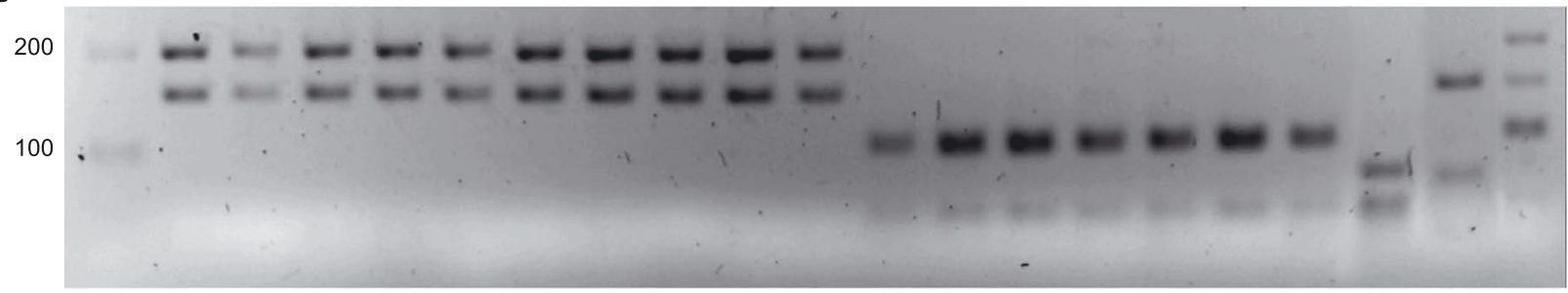

Fig. 3. Electrophoretic separation and visualization of: A - PCR reaction results with FrUNIF/FrUNIR primers with 10 populations of F. occidentalis, seven populations of $F$. intonsa, one population of F. pallida and one population of $F$. tenuicornis; B - PCR-RFLP products obtained using TruI and HinfI restriction enzymes for DNA obtained from all analyzed Frankliniella populations; F.p. - F. pallida, F.t. - F. tenuicornis, F.o. - F. occidentalis, F.i. - F. intonsa. PCR-RFLP products sizes are as follows: $190 \mathrm{bp}$ and $147 \mathrm{bp}$ for F. occidentalis; 102 bp, $95 \mathrm{bp}$ and $50 \mathrm{bp}$ for F. intonsa; 68 bp, 50 bp, 44 bp, 42 bp and 35 bp for F. pallida and 151 bp, 68 bp and 36 $\mathrm{bp}$ for F. tenuicornis according to bioinformatics tool used for prediction of products fragments sizes after restriction enzymes digestion (NEBcutter V2.0). After gel electrophoresis some bands of similar size migrated together during electrophoresis; $\mathrm{M}$ - marker of molecular weight (Nova 100 bp Novazym)

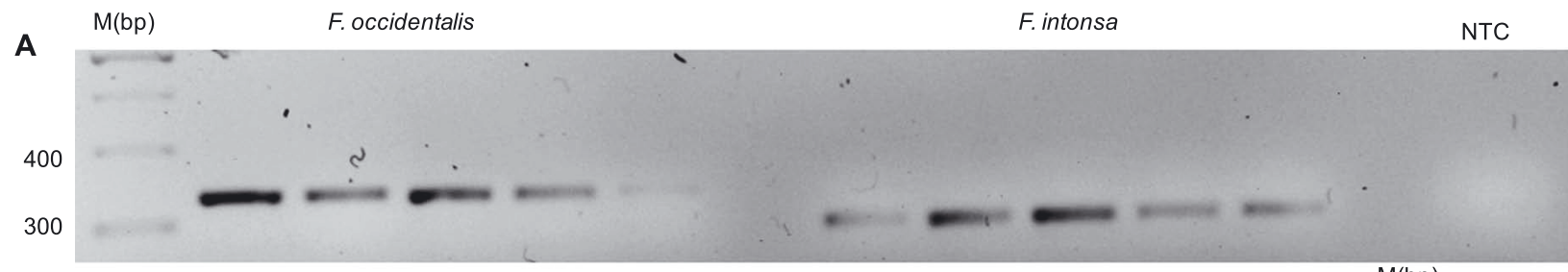

B

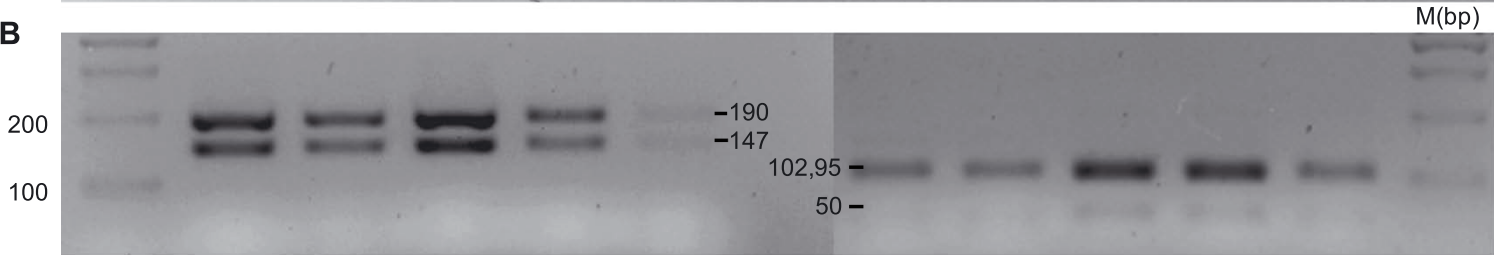

Fig. 4. The separation of PCR products during electrophoresis in agarose gels: A - PCR products obtained with FrUNIF/FrUNIR primers on one larva without DNA extraction step; B - RFLP reaction results for one larva without DNA extraction step; NTC - no template control, M - marker of molecular weight (Nova 100 bp Novazym) 


\section{Discussion}

Thrips species in the genus Frankliniella are polyphagous pests that feed on a variety of ornamental and vegetable hosts. F. occidentalis and F. intonsa are both efficient vectors of viruses and are major pests feeding on a number of crop species. Since most Frankliniella species are highly polyphagous and are commonly found on plants as larvae which usually have not developed the morphological characteristics of adults, identification at a species level requires growth to adulthood (Huang et al. 2010). Classical morphological studies regarding insects belonging to the Frankliniella genus species show deficiencies in identifying both interspecific and natural strains of the same species. These are characterized by considerable phenotypic variation relating to morphological traits, such as size and position of the ocellar setae. But it is not always easy, because $F$. intonsa is very similar to $F$. occidentalis. These less stable traits should therefore be coupled to other distinctive features to make the identification more reliable. Accordingly, molecular biology techniques are a valuable addition to traditional phenotypic methods of pest thrips recognition (Moritz et al. 2004).

There are some PCR-RFLP protocols for F. occidentalis and F. intonsa (Mainali et al. 2008), Hercinotrips femoralis, F. occidentalis, T. palmi, T. tabaci and Heliothrips haemorrhoidalis (Brunner et al. 2002) as well as for F. occidentalis, F. intonsa, T. hawaiiensis, T. coloratus, T. flavus, T. palmi, T. tabaci and T. setosus (Toda and Komazaki 2002). However, to date there is no method which can differentiate four of the species analyzed in this study. Furthermore, there is no molecular diagnostics protocol for F. pallida and F. tenuicornis. To fill this gap we have undertaken to develop a protocol which would make it possible to both detect and differentiate the four Frankliniella species.

The method described by Mainali et al. (2008) to distinguish F. occidentalis and F. intonsa species may result, as stated by the authors, in false positives for $F$. intonsa when one sample contains both species. This deficiency has been eliminated in our protocol which allows for the differentiation of F. intonsa and F. occidentalis even in the preliminary PCR reaction, before RFLP, when both species are mixed in a single sample (Fig. 3A). As a product of this reaction two single bands with sizes specific for each species (F. occidentalis -326 bp, F. intonsa - 237 bp) are observed. Since F. occidentalis and $F$. intonsa are found sympatrically in fields and greenhouses (Ullah and Lim 2015), proper identification of this species is particularly relevant.

Protocol is useful for identification all Frankliniella species occurring frequently not only in Poland but also in other countries. Frankliniella nigriventris and F. tristis which were not tested during this study have been reported in Poland only a few times so far and their significance is marginal (Sierka and Gocyła 2004). Moreover, their rDNA sequences in public databases are lacking. In our preliminary study we first aligned all known Frankliniella sequences from GenBank including one additional Frankliniella species not tested in our study, which until now has not been reported in Poland - F. schultzei. Frankliniella schultzei is a polyphagous pest feeding on various ornamental and vegetable hosts in different parts of the world including Europe. This pest can cause both direct and indirect damages to crop. It feeds on pollen and floral tissue, leading to flower abortion. Indirect damage is due to virus transmission (Kakkar et al. 2010). The sequence analysis done showed that the PCR primers described in this study are not able to bind to rDNA of F. schultzei and thus to amplify DNA of this species (Fig. 1).

The PCR-RFLP method described in this study is fast, simple and relatively cheap because it allows for the identification of one larva of $F$. occidentalis and F. intonsa even without DNA extraction and it does not require any additional equipment except for a thermal cycler and electrophoresis set.

\section{Acknowledgements}

This study was supported by the Polish Ministry of Agriculture and Rural Development, the Long-Term Programme of IPP - NRI, Project 2.7 (to AOS). Some thrips populations were kindly provided by Dr Halina Kucharczyk from University of Maria Curie-Skłodowska in Lublin, Poland.

\section{References}

Brunner P., Fleming C., Frey J. 2002. A molecular identification key for economically important thrips species (Thysanoptera: Thripidae) using direct sequencing and a PCR-RFLPbased approach. Agricultural and Forest Entomology 4 (2): 127-136.

EPPO A. List of pests recommended for regulation as quarantine pests. EPPO (version 2014-09). Available on: http://www. eppo.org/QUARANTINE/listA2.html.[Accessed:August28, 2015]

Hall T.A. 1999. BioEdit: a user-friendly biological sequence alignment editor and analysis program for Windows 95/98/NT. Nucleic Acids Symposium Series 41: 95-98.

Huang C.-G., Hsu J.-C., Haymer D.S., Lin G.-C., Wu W.-J. 2009. Rapid identification of the Mediterranean fruit fly (Diptera: Tephritidae) by loop-mediated isothermal amplification. Journal of Economic Entomology 102 (3): 1239-1246.

Huang K., Lee S., Yeh Y., Shen G., Mei E., Chang C. 2010. Taqman real-time quantitative PCR for identification of western flower thrip (Frankliniella occidentalis) for plant quarantine. Biology Letters 6 (4): 555-557.

Kakkar G., Seal D.R., Jha V.K. 2010. Common blossom thrips, Frankliniella schultzei Trybom (Insecta: Thysanoptera: Thripidae). Available on: http://edis.ifas.ufl.edu/pdffiles/ IN/IN86000.pdf [Accessed: August 28, 2015]

Kraus M.S.G., Moritz G. 1998. Molecular genetic studies of thrips species. p. 77-80. In: Proceedings of the 6th International Symposium on Thysanoptera, Akdeniz University, Antalya, Turkey, 27 April-1 May 1998.

Kucharczyk H. 2007. Wciornastki. [“Thrips“]. p. 391-398. In: "Fauna Polski: charakterystyka i wykaz gatunków" [“Fauna of Poland. Characteristics and Checklist of Species"]. Vol. 2. (W. Bogdanowicz, E. Chudzicka, I. Pilipiuk, E. Skibińska, eds.), Muzeum i Instytut Zoologii PAN, Warszawa, 509 pp.

Mainali B.P., Shrestha S., Lim U.T., Kim Y. 2008. Molecular markers of two sympatric species of the genus Frankliniella (Thy- 
sanoptera: Thripidae). Journal of Asia-Pacific Entomology 11 (1): 45-48.

Marullo R. 2002. Impact of an introduced pest thrips on the indigenous natural history and agricultural systems of southern Italy. p. 285-288. In: "Thrips and Tospoviruses". Proceedings of the 7th International Symposium on Thysanoptera, Australian National Insect Collection, Reggio Calabria, Italy, 02-07 July 2001.

Marullo R. 2003. Conoscere i Tisanotteri. Guide al riconoscimento delle specie dannose alle colture agrarie. Edagricole, Bologne, Italy, $75 \mathrm{pp}$.

Moritz G., Mound L., Morris D., Goldgrazena A. 2004. Pest thrips of the world. An identification and information system using molecular and microscopical methods. CD ROM, University of Qeensland, Brisbane.

Moritz G.D.C., Paulsen M., Mound L.A., Burgermeister W. 2000. Modern methods for identification of Thysanoptera. EPPO Bulletin 30: 591-593.

Nakahara S. 1997. Annotated list of the Frankliniella species of the world (Thysanoptera: Thripidae). Contributions on Entomology, International 2 (4): 355-389.

Nicholas K.B., Nicholas Jr H.B., Deerfield II D.W. 1997. Gene Doc: analysis and visualization of genetic variation. Embnet News 4: 1-4.

Obrepalska-Steplowska A., Nowaczyk K., Holysz M., Gawlak M., Nawrot J. 2008. Molecular techniques for the detection of granary weevil (Sitophilus granarius L.) in wheat and flour. Food Additives and Contaminants 25 (10): 1179-1188.

Pobożniak M. 2011. Dynamika populacji Frankliniella intonsa (Thysanoptera) na warzywach bobowatych. [Population dynamic of Frankliniella intonsa (Thysanoptera) on legumes vegetables]. Progress in Plant Protection 51 (3): 1058-1062.

Przybylska A., Fiedler Ż., Kucharczyk H., Obrępalska-Stęplowska A. 2015. Detection of the quarantine species Thrips palmi by loop-mediated isothermal amplification. PloS ONE 10 (3): e0122033.
Pumariño L., Alomar O., Agustí N. 2011. Development of specific ITS markers for plant DNA identification within herbivorous insects. Bulletin of Entomological Research 101 (3): 271-276.

Rebijith K., Asokan R., Kumar N.K., Krishna V., Ramamurthy V. 2012. Development of species-specific markers and molecular differences in mtDNA of Thrips palmi Karny and Scirtothrips dorsalis Hood (Thripidae: Thysanoptera), vectors of tospoviruses (Bunyaviridae) in India. Entomological News 122 (3): 201-213.

Sierka W., Gocyła A. 2004. A survey and geographical distribution of the thrips (Insecta, Thysanoptera) in Poland. Thysanopteron 1: 24-57.

Toda S., Komazaki S. 2002. Identification of thrips species (Thysanoptera: Thripidae) on Japanese fruit trees by polymerase chain reaction and restriction fragment length polymorphism of the ribosomal ITS2 region. Bulletin of Entomological Research 92 (4): 359-363.

Ullah M.S., Lim U.T. 2015. Life history characteristics of Frankliniella occidentalis and Frankliniella intonsa (Thysanoptera: Thripidae) in constant and fluctuating temperatures. Journal of Economic Entomology 108 (3): 1000-1009.

Varadínová Z., Wang Y., Kučerová Z., Stejskal V., Opit G., Cao Y., Li F., Li Z. 2015. COI barcode based species-specific primers for identification of five species of stored-product pests from genus Cryptolestes (Coleoptera: Laemophloeidae). Bulletin of Entomological Research 105 (2): 202-209.

Wang C.-L., Lin F.-C., Chiu Y.-C., Shih H.-T. 2010. Species of Frankliniella Trybom (Thysanoptera: Thripidae) from the Asian-Pacific Area. Zoological Stuies 49 (6): 824-848.

Zhang G., Meng X., Min L., Qiao W., Wan F. 2012. Rapid diagnosis of the invasive species, Frankliniella occidentalis (Pergande): a species - specific COI marker. Journal of Applied Entomology 136 (6): 410-420. 